\title{
The challenge of ensuring effective early years music education by
} non-specialists ${ }^{1}$

\author{
Graham F Welch \\ UCL Institute of Education
}

\section{Abstract}

The article reports research concerning the potential and actual benefits for young children in engaging in musical activities, whether in the home or outside, such as in community nursery settings and schools. The research literature suggests that music can support a wide range of psychological, social and physical behaviours and development. However, there is a paradox in that many teachers and teaching assistants of young children are likely to have a somewhat limited professional knowledge of how best to organise effective music education. They may also be unaware of how to maximise music's wider benefits. One possible solution is to effect appropriately mentored professional development with experienced early years music specialists. Evidence of how such professional development can make a difference is exampled in several recent and ongoing workplace-based case studies from the UK and Australia.

\section{Key words}

Music, children, wider benefits, teachers, mentoring

\section{Introduction}

One of the perennial challenges in music education in both nursery and Primary schools is the relative mismatch between the requirements for a teacher to have 'generalist' subject knowledge that covers a diverse range of subjects compared with a more 'specialist', in-

\footnotetext{
${ }^{1}$ Accepted $29^{\text {th }}$ June 2020 for Early Child Development and Care Special Issue on 'Music in the Lives of Young Children'
} 
depth knowledge that is perceived to be a necessary requirement to teach music. This conceptual mismatch was highlighted in England when, soon after the passing of the Education Reform Act in 1988 and its introduction of an initial 'National Curriculum' for schools, the then Secretary of State for Education, Kenneth Clarke, commissioned a report from three senior education figures. Robin Alexander (Professor of Primary Education), Jim Rose (Chief Inspector, Her Majesty's Inspectorate [HMI]) and Chris Woodhead (Chief Executive, National Curriculum Council) were tasked with providing a contemporary expert challenge to what was seen as the influential preoccupation from the 1960 's with 'childcentred' approaches to learning, especially as characterised in the influential Plowden Report (CACE, 1967). The (Conservative) Secretary of State hoped to have support for a more 'traditional' view of teaching methods that would be more 'in-tune' with the new political focus on curriculum content, as well as addressing the perceived national need to improve children's literacy and numeracy. The subsequent report by Alexander, Rose and Woodhead (DES, 1992) suggested that 'The resistance to subjects at the Primary stage is no longer tenable' (p1).

Furthermore, the three authors believed that an effective Primary teacher should have three kinds of expertise: (i) subject knowledge (having expertise in subject content), (ii) pedagogy (knowing how children learn) and (iii) the management of learning (knowing how to organise the learning environment, such as related to time, physical space and resources) (p5o).

This triadic view of the role of the teacher persists to the present day, despite the contested nature of how to define 'music', 'development' and 'pedagogy', not least because each subsequent iteration of the National Curriculum in England since 1989 has continued to have a strong emphasis on subject knowledge, albeit biased towards certain subjects as 'core', such as English, mathematics and science, and with others, such as the arts, being somewhat more peripheral. This marginalisation has increased over the past decade with the introduction in Secondary schools of an 'English Baccalaureate' (EBacc) (DFE, 2010; DFE, 2019) in which arts subjects, including music, are not included (Bath, Daubney, Mackrill \& Spruce, 2020; Welch, 2011, 2012a; Zeserson, Welch, Burn, Saunders, \& Himonides, 2014). 
It is no surprise, therefore, that-given this curricular bias towards a 'core curriculum' - the pre-service and in-service preparation of nursery and Primary teachers often provides limited opportunities for engagement in arts pedagogy, including music. This inadequacy in professional experience is reported in England (cfHennessy, 2010; Welch \& Henley, 2014; Poulter \& Cook, 2020), as well as elsewhere in the world, such as Scotland (Bhachu, 2019), Australia (Letts, 2015; Barrett, Flynn, Brown \& Welch, 2019) and Singapore (Chua \& Welch, 2019).

\section{The potential wider benefits of music education}

Paradoxically, notwithstanding this marginalisation of the arts in education policy, there is a growing research literature on the benefits of artistic engagement in nurturing children's wider progress, such as in literacy and numeracy, as well as their physical, psychological (including emotional) and social development. Examples of arts benefits with young children include longitudinal research data from Finland (Linnavelli et al, 2018) concerning 5-6-year-old children attending a low-cost community-based music playschool. Over two school years, these young children were found to have significant improvements in the development of phoneme processing and vocabulary skills compared to peers who had not attended such a setting. This outcome is in line with other recent neuroscience research into children's phonological processing (Zuk et al., 2018), and is also related to the wider cognitive benefits that are reported to arise from playing a musical instrument, such as for 0.5 hours a week or more (Loui et al., 2019). In this latter study, the 8-9-year-old instrumental learners tended to develop statistically significant higher measurable verbal ability and better general intellectual ability than their non-instrument learning peers.

One underlying reason for such an improvement is because structured musical experience is likely to promote enhanced sound discrimination and encoding, and to enhance phonological processing and reading ability (Putkinen et al., 2019). This finding is echoed in another recent empirical study of 3-4-year-olds which reported 'compelling evidence that both melodic and timing aspects of musical processing are associated with measures of phonological awareness and grammar' (Politimou et al., 2019, p10). 
Therefore, it is plausible that musical activities involving active manipulation of rhythm and pitch contour are likely to support the perceptual development of prosodic features in language. Such a hypothesis has support from neuroscientific research findings related to common features in (a) the sensory encoding of sound, (b) musical melodies and linguistic intonation contours, as well as (c) the interactions between linguistic and musical syntactic processing (Patel, 2008). A recent set of studies with two different age groups (5-year-olds and 8-year-olds) in Germany (Steinbrink et al., 2019) investigated temporal and spectral auditory processing abilities in children. In both studies, rhythm reproduction and pitch perception abilities were significant predictors of phonological awareness.

Overall, there are a wealth of studies to suggest that successful engagement in musical activities can support children's wider development, including general intellectual functioning (Schellenberg, 2004; 2016), spatial and verbal skills (Forgeard et al., 2008; Rauscher \& Hinton, 2011), mathematical skills (Haimson et al. 2011), aspects of executive function (Bowmer et al, 2018), social inclusion (Alemán et al, 2017; Welch et al, 2014) and language and literacy (Anvari et al., 2002; Clift, Mackenzie \& Bushell, 2007), including preliteracy skill development in the early years (Moreno, Friesen \& Bialystok, 2011; Williams et al, 2015). Furthermore, children's general behaviour can also improve, as exampled by an innovative, school-based, three-month orchestral programme in Italy with $n=113$ 8-10year-olds that was found to be particularly beneficial in reducing hyperactivity, inattention and impulsivity, whilst enhancing inhibitory control (Fasano et al., 2019). (For more recent research examples of the wider benefits of music, see the new e-book collection edited by Biasutti, Welch, MacRitchie, McPherson \& Himonides, 2020).

These potential benefits from engaging in musical activities are in a context where the latest school census data in England (2019) indicate that poor speech, language and communication skills (SLC) are the largest special needs category for children in Primary schools in England, embracing $n=173,401$ children or $22 \%$ of all pupils. Perhaps even more significantly, at the youngest age for which data are available, such SLC needs are evidenced in approximately $60 \%$ of 4 -year-olds. 
However, given the weaknesses concerning arts education in their professional preparation, how to initiate appropriate musical activities is not always known by early years and Primary practitioners. Similarly, it is unlikely that such professionals are fully aware of the research evidence concerning music's practical value in supporting children's broader academic development (cfBarrett, Flynn, Brown \& Welch, 2019).

\section{Addressing the music education needs of non-music specialist generalist teachers and nursery staff}

Several research studies over the past three decades have commented on generalist teachers' 'lack of confidence' to teach music in Primary school settings. Such reports are evidenced from various countries around the world, including England (Hennessy, 2000; Holden \& Button, 2006; Mills, 1989; McCullough, 2006; Seddon \& Biasutti, 2008; Stunell, 2010; Welch \& Henley, 2014); Australia (Auh, 2004; Ballantyne, 2006; de Vries, 2013; Jeanneret, 1997); Ireland (Stakelum, 2008); Scotland (Bhachu, 2019); Brazil (Figueiredo, Soares \& Schambeck, 2015); and Portugal (Mota, 2015); and also in comparative studies across several countries, including Australia/USA/Namibia/South Africa/Ireland (RussellBowie, 2009).

Evidence related to a 'lack of confidence' that is derived from a sense of personal musical inadequacy has also been reported by nursery teachers, such as in Norway (Kulset \& Halle, 2019) and England (Digby, 2020), as well as in pre-service students who are studying to become Primary teachers (Hallam et al., 2009). A recent news item in the weekly professional magazine for teachers, the TES on $5^{\text {th }}$ October 2018 , reported on a Headteachers' (NAHT) conference at which the Deputy Director of Ofsted (the statutory body responsible for the oversight of teaching quality in English nurseries and schools, herself an ex-Reception class teacher of $5 y$ o in a Primary school) commented that 'young children need singing'. She suggested that nursery teachers were too embarrassed to sing in front of other people, in part because they tend to compare themselves negatively to high quality sung music performance that is easily available via new technology, such as on their mobile phones. 
This 'lack of confidence' is thought to stem from several persistent socio-cultural and educational biases.

- Firstly, there is a continuing widespread misconception that musicality is defined by success in Western Art music.

- Using this definition, musicality is, therefore, confined to a small sub-group of the general population (e.g., Ruddock \& Leong, 2005). This is despite the wealth of neurological evidence to the contrary that we are all musical by design ( $c f$ Blacking, 1976; Hodges, 2019; Schlaug, 2015; Welch \& McPherson, 2018).

- Thirdly, as mentioned above, the relative marginalisation of the arts (including music) in the English Secondary school curriculum from age 14 years is characterised by their absence from the English Baccalaureate (2019) that was introduced in England in 2011. Analyses on examination entry data report that less than $10 \%$ of the secondary school pupil population continue to study music through to the General Certificate of Secondary Education (GCSE) at age 16 years, and beyond (Welch, in press). One related outcome is that the pool of skilled, confident musicians in the general population from which the future Primary generalist teaching force will be recruited is small (Welch, 2012b).

- Fourthly, Initial Teacher Education (ITE) for intending Primary teachers in England usually covers the ten subject areas of the National Curriculum, plus Religious Education. Accordingly, there is relatively little time allocated to arts education, including music, because of the pressures for new teachers to be demonstrably expert in the core subject areas (and associated sub-areas) of English, mathematics and science.

- These biases in professional preparation are compounded in early childhood and care settings, where the workforce tends to be young and female, with relatively limited experience and formal qualifications in education (Peeters et al., 2015; Barrett, Flynn, Brown \& Welch, 2019), as well as in music.

One consequence of these challenges to the provision of effective music education in nursery and Primary schools has been various initiatives to improve the quality of pre- and in-service teacher (and Teaching Assistant) preparation. The intention has been to ensure that teachers have at least a basic, foundational knowledge concerning appropriate musical 
activities and pedagogical approaches in music with young children. In England, the Government initiated a National Plan for Music (DFE, 2011) for all children and young people (and due to be published in revised form in 2020). A key to the success of this national policy was to ensure that increasing numbers of Primary teachers were capable of teaching music (however, the Plan did not cover children under the age of five years, the statutory age for the commencement of children's formal education in England).

One related outcome in 2011 was an initiative by the Training and Development Agency (TDA) for Schools, the official UK Government quango in England at that time that was charged with the national supply and quality of teachers. The TDA funded research into the design, teaching and evaluation of pilot music modules as part of Primary Initial Teacher Education (ITE) courses (see Hennessy, 2017 for an overview). The aim was to boost the confidence and competency of new Primary teachers in music education. Twenty-one pilot modules were funded and trialled across the higher education sector by individual ITE providers in 2012-2013. A basic requirement in the course designs was for the student teachers to spend some of the module (course) time in schools, to observe experienced teachers of music, to enact their own suitable music curricula activities, and to have time for related design and reflection (see Welch \& Henley, 2014 for a report of one example of module design and evaluation). Evaluations by the ITE providers suggested that these local short-term initiatives were relatively successful and, in some cases, became integrated into the ongoing Primary ITE curricula (Hennessy, 2017).

\section{The value of workplace mentoring non-music specialist generalist teachers and nursery staff}

Nevertheless, a common challenge in seeking better long-term outcomes of such initiatives is how to ground the professional (pre/in-service) development in music education in the realities of the nursery and Primary school settings. One solution has been to place appropriately prepared and skilled musicians to work alongside and mentor the lessmusically confident generalists, together with their pupils, and supported by sufficient time for shared planning and reflection. Workplace mentoring has been described as the relationship between an experienced individual (the mentor) and a less experienced 
individual (the mentee) in the workplace that aims to assist the personal and professional growth of the mentee (Kram, 1985). Workplace mentoring typically takes place over extended periods of time and is multi-faceted in nature (Eraut, 2011).

A recent Australian example has reported on the positive impact that a generalist teacherled pilot music programme has had on early childhood school children's singing skills and attitudes to music (Barrett, Zhukov \& Welch, 2019; Barrett, Zhukov, Brown \& Welch., 2020). The programme aimed to address a lack of music training during undergraduate teacher preparation, as well as a perceived lack of confidence in music teaching and singing amongst generalist (non-music specialist) classroom teachers. Those chosen as mentors participated in a two-day workshop that addressed mentoring skills and the music programme content. During the workshop, mentors were tutored on the fundamentals of mentoring and shared simple strategies, practices and resources for engaging teachers and their children in effective music education. A similar approach to the training of mentors had been implemented in the USA (Berg and Conway, 2016). Subsequently, the Australian mentors worked with generalist classroom teachers in a one-to-one mentoring relationship over an extended period of time, being two school terms in New South Wales (20 weeks) and one school term in Victoria (10 weeks).

'The mentors visited the allocated schools and assessed local resources; invited mentees to observe mentors' music teaching; collaborated in developing music lesson plans and activities that addressed individual teacher goals, needs and context; co-taught music with mentees during classroom lessons; and observed and provided feedback on the mentees' music teaching. Music curricular content was essentially voice-based, with a literacy focus, and included simple instrumental work that was informed by Kodaly and Orff principles.' (Barrett, Zhukov \& Welch,2019, p5)

Singing tests and class surveys were administered to students in the $n=11$ participant Australian Primary schools before and after the mentoring programme. Two hundred and ninety-two children participated in singing tests and surveys. The children were aged $4-8$ years and were drawn from early years (reception classes) and primary school years 1 and 2. The number of children in the mentored classes was 237, with 55 children in the control classes of matched year level. The results showed that, as well as having a positive impact on adult participants' music knowledge and confidence, the implementation of these music activities in early education settings impacted positively on young children's singing skills 
and attitudes to music, regardless of gender, ethnicity and socio-economic standing of the school (Barrett, Flynn, Brown \& Welch, 2020) (Figure 1).

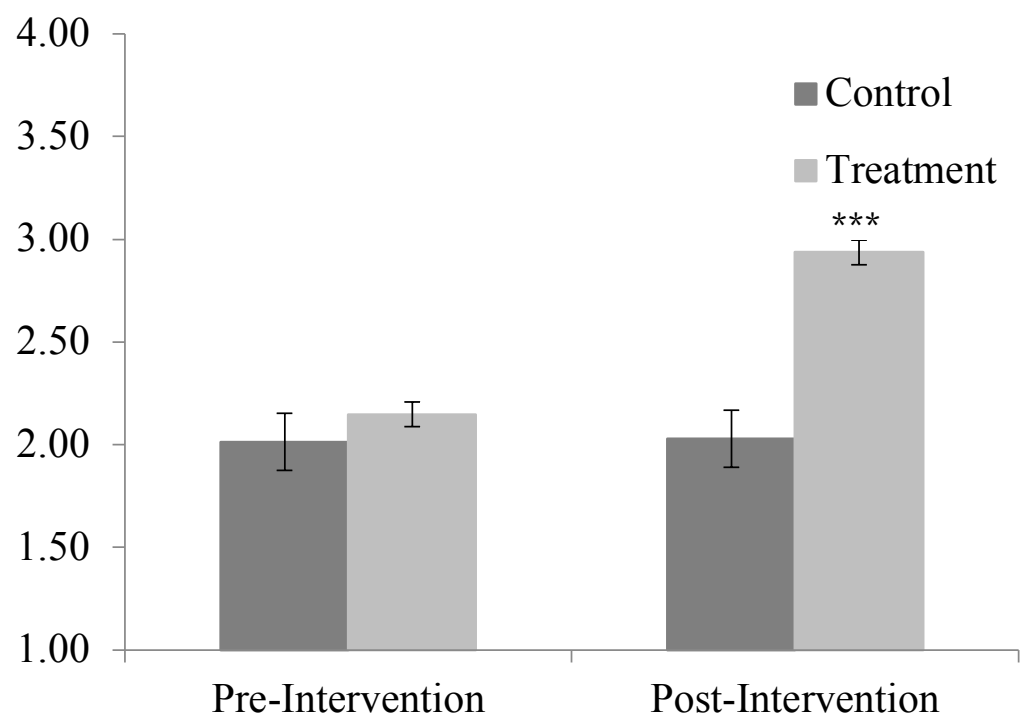

Figure 1. Mean ratings of student singing ability according to time of assessment, as moderated by intervention group. Error bars represent standard errors. Comparisons were performed between the pre-intervention and post-intervention time points within each of the control and treatment intervention conditions. $* * * p<.001$. (Barrett et al, 2020, p127)

In a similar, smaller-scale initiative in England, mentors from the VOCES8 Foundation recently worked with generalist (non-music specialist) class teachers and their pupils in two Hackney Primary schools in inner London. Initial, teacher-only, sessions with mentors were followed by in-class mentoring over two school terms, totalling eight one-hour sessions over approximately six months. Participant children were aged between 5.2 and 6.3 years. Data analyses are based on $n=63$ children across the three participant schools, $n=46$ in the two intervention schools and $n=17$ in the control school. Evaluative data included evidence of significant benefits in participant children's singing, as well as non-musical development in children's reading and aspects of their Executive Function (Welch et al., 2020). The children's singing development was assessed using the same rating scale (Welch, 1998) as in the earlier Australian study (Barrett et al, 2020). Overall, there was a significant improvement in children's singing $(F(1,60)=10.612 ; p<0.01)$, particularly in three of the four intervention classes. 


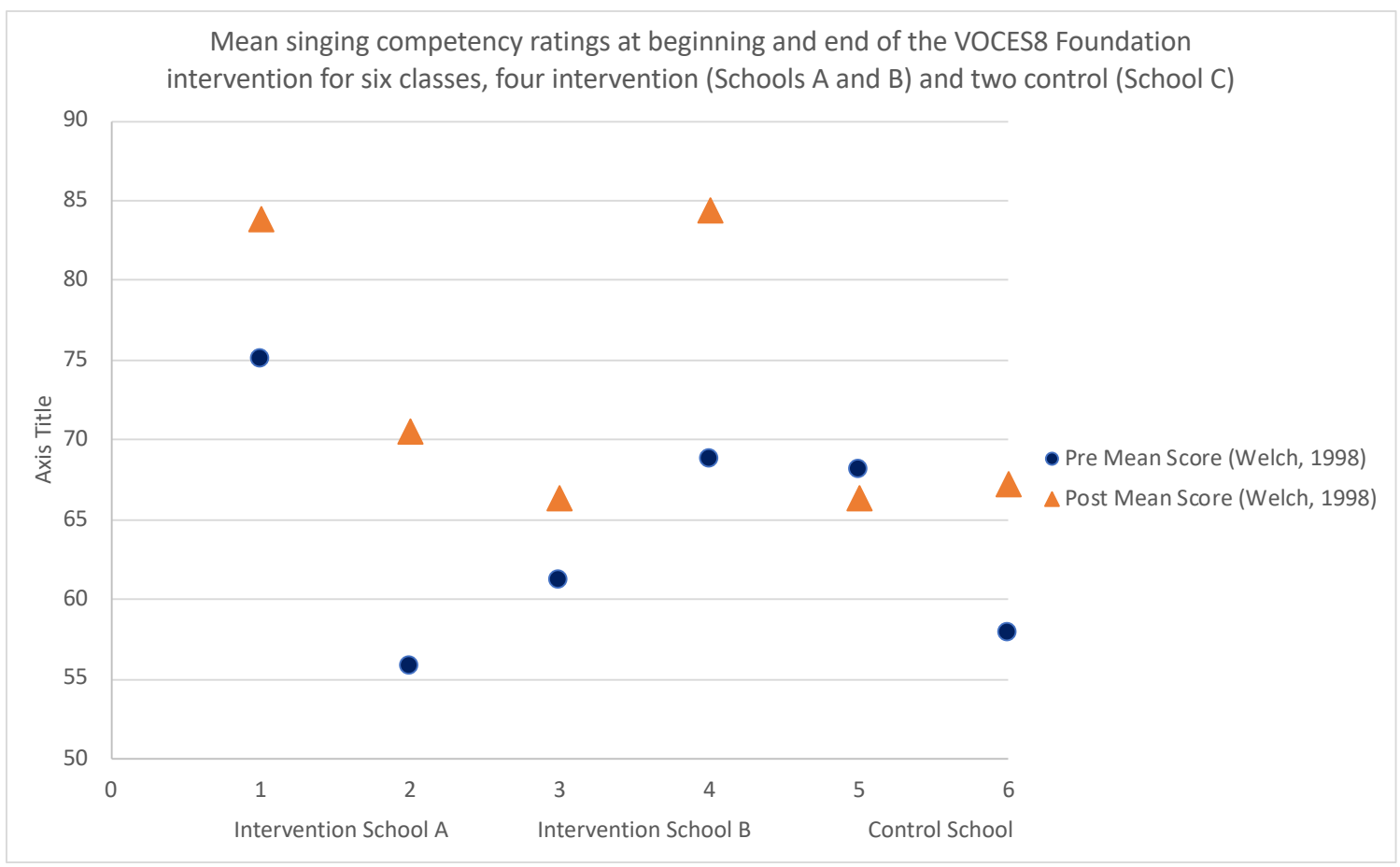

Figure 2: Mean singing competency ratings (using the Welch, 1998 rating scale) for each of the six participant classes over time ( 4 intervention classes and 2 control classes)

Observations also took place of music classes led by the class teachers when the mentors were absent. These indicated that the participant teachers had developed music education knowledge and skills, as well as confidence in leading singing activities with the participant 5-6-year-olds.

One particular type of music mentoring in UK has focused on supporting young children's speech, language and communication (SLC) development through music. In London, for example, the 'Music for Change' project set out to explore the impact of a specially devised programme of weekly music sessions on the all-round development of pre-school children in northwest Westminster, an area of inner-city multiple deprivation (Knight, et al, 2018). The project was devised by the London-based charity 'Creative Futures' with the aim of improving children's school readiness by supporting the development of high numbers of children with SLC needs. In this part of London, almost a third of children are registered as having some form of special educational need or disability (SEND) and an estimated $50 \%$ of children have some form of speech and language delay. More than $60 \%$ have English as an Additional Language (EAL) and, in some schools, this proportion rises to almost $100 \%$. 
Accordingly, 'Music for Change' brought together a speech and language therapist (SLT), funded by the local National Health Service (NHS), and a specialist early years musician to work collaboratively alongside each other in local community nursery settings, primarily for a period of ten weeks. The two specialists led a weekly, action research cycle that enabled them to support the resident nursery practitioners in musical activities that included language and communication foci. Over the ten weeks, the nursery staff initially observed the specialists working with their children and then, gradually, took on more and more responsibility for leading the hour-long weekly music sessions. Practice was based on vocal play, singing, using sound-making objects, musical games, listening and aural discrimination, movement, and songs and stories ( $c f$ Welch \& Preti, 2019). The inclusion of free musical play activities, led by the young children, also allowed for the emergence of improvised songs from the children. In addition, the narration of children's play in song form was found to be helpful for introducing language and for enhancing the adult-child interactions by supporting adult reflection on what children were doing.

Across the two years (2015-2017), the 'Music for Change' project involved work in $n=11$ different nursery settings with $n=1,320$ children aged $0-4$ years and included $n=871$ workshop sessions. Amongst the impact findings were empirically-based evidence of children's development in music, as well as through music - including personal, social and emotional development, such as increased listening, attention and communication skills. In addition, there were positive impacts on the professional development and behaviours of nursery staff, in terms of both confidence and competence in using musical activities to support children's speech and language development (Knight et al, 2018). Furthermore, the pedagogical scaffolding of activities by the two visiting experts, in which there were opportunities for children and nursery staff to lead at different moments, empowered and enabled both children and staff to have a sense of agency and ownership within and of the programme (Welch \& Bowmer, 2017).

A key strand of the Music for Change evaluation focused on the musical development of forty-six pre-school children over a period of 33 weeks (Knight et al, 2018). The evaluation tool was the Sounds of Intent in the Early Years (Sol-EY) musical development framework 
(Voyajolu \& Ockelford, 2016). Across two years, the children made significant progress in their musical development from being considerably below their age-related-expectations $(A R E)$ to much more in line with their age group. Figure 3 illustrates the underlying musical development for these children across the period for one aspect, their pro-active music making. This shows a strong linear trend in pro-active Sounds of Intent levels from around 2.8 to 4.4 (with Level 5 being the highest possible). The children in the study began the intervention at the age of 3 years 3 months, and were, according to the baseline assessments that were made, very significantly behind musical ARE (Sounds of Intent level 2.8 rather than 4.1). 'The intervention meant that their musical development accelerated considerably, moving to a music-developmental age that was slightly (though not statistically significantly) ahead of musical ARE (o.1 of a Sounds of Intent level)' (Knight et al, 2018, p9).

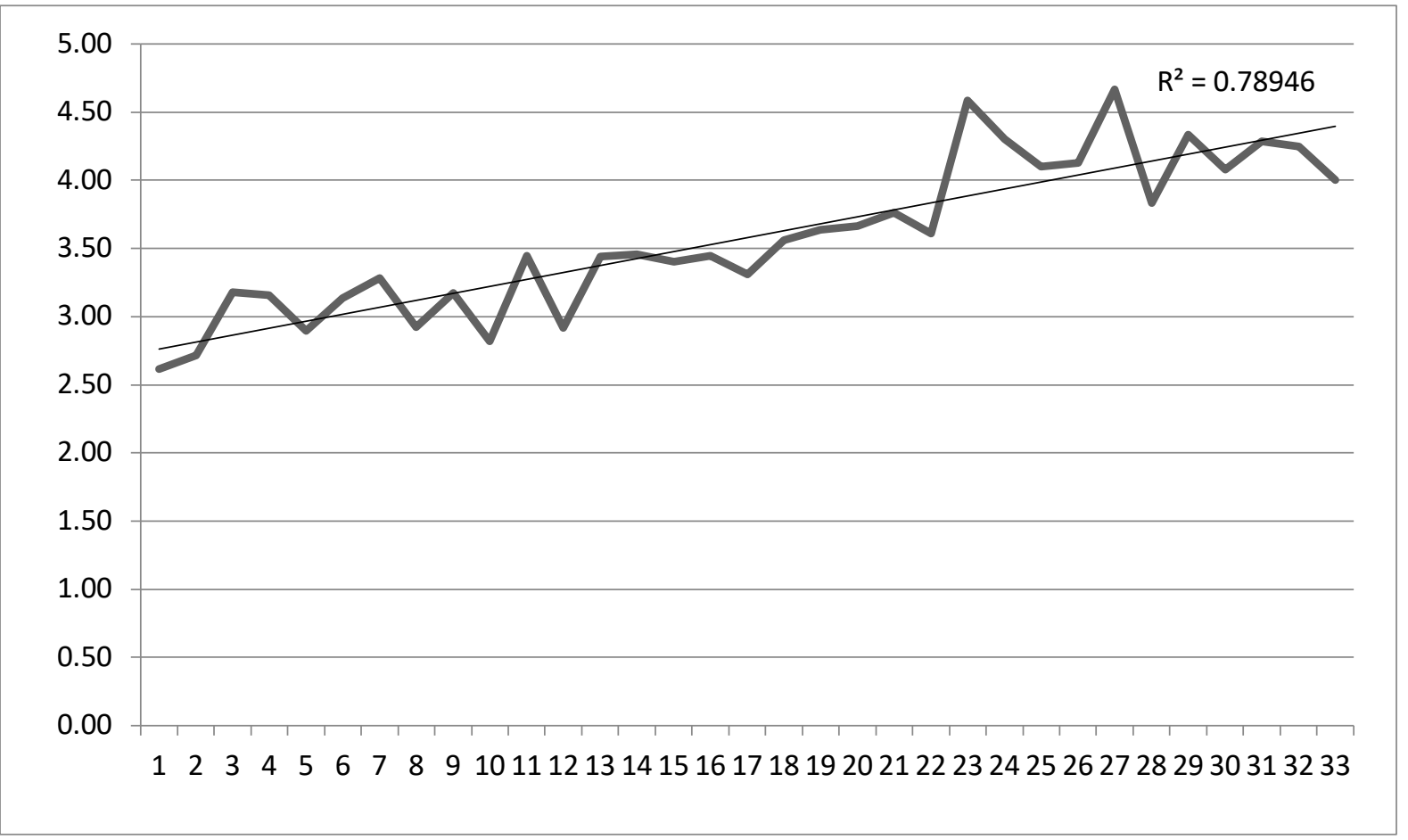

Figure 3: The linear trend in the development of $\mathrm{N}=46$ children's pro-active musical behaviours across 33 weeks in the Music for Change programme (Knight et al, 2018, pg).

Furthermore, longitudinal assessments of the same children using the official national preschool 'Early Learning Goals' for the Early Years Foundation Stage (DFE, 2017) found that 
there were improvements - over and above what would normally be expected from natural maturation - in speaking, making relationships (and with larger changes occurring in listening and attention), and managing feelings and behaviour.

A similar programme of pre-school professional development was undertaken in Norfolk, an area to the east of London. The action research design of the 'SALTMUsic'project brought together speech and language therapists and early childhood music practitioners to develop new pedagogical approaches in their work with families whose children (aged 24-36 months) had communication difficulties. Children and their families attended regular sessions from between three months and a year and reported similar benefits to those found in London, with 90\% of parents stating that their children's language had improved, and practitioners asserting that they had grown in confidence in using musical approaches for therapeutic development of speech, language and communication (Pitt \& Arculus, 2018).

Following the success of the 'Music for Change' programme in London (2015-2018), with its focus on pre-school children with SLC needs (see above), a follow-up 'Sound Communities' programme was launched. This was designed to provide free music-focused professional development for nursery staff in locations in South East England where there are above average proportions of children with English as an Additional Language (EAL), or who have SLC needs. The overarching aim has been to enable resident nursery staff to add and enrich music-based opportunities and activities into their daily routines in school with young children'. The programme was launched in 2018 and continues to 2021.

Over the Autumn school term (September to December 2019), staff from seven nursery settings in Hastings and St Leonards, East Sussex attended three two-hour workshops (September, November, December) as part of the second year of the 'Sounds Communities' programme. The first two workshops took place at the end of the school day in one of the partner locations. The opening session was designed to provide an introduction to 'music and communication' and was followed in session two by a more specific focus on 'the building blocks of music'. The third session, 'observing and documenting musical play', took place in the host school after lunchtime and involved group discussions either side of a visit 
to the onsite nursery. The visit provided an opportunity for course participants to observe and talk to the young children and their staff in situ.

In each session, the participants were required to act musically, such as to manipulate sound and to make music - including by using their hands, voices, simple instruments. They also were provided with opportunities to use other media as sound accompaniments, such as drawing materials and scarves. Focused listening was a common key activity, as was talk following listening. Sound games were another key component, often generating much humour.

Throughout, the participants' behaviours suggested that they were intellectually and emotionally engaged in the content of the sessions and were willing to share, discuss, and make music. It was clear from their comments, personal examples and body language that participants were positively involved in elements of the programme. Participants took the opportunity provided by the mentor(s) to offer illustrative craft knowledge examples of how personally they had applied the previous session's content in their own nursery, gaining hands-on experience with their own children. Examples included the use of found instruments, observing children's own sound and music making, and singing whilst doing other things.

Of the three 'Sound Communities' sessions, perhaps session two was the most challenging, as this was focused on engagement with the building blocks of sound - the elements of music, such as pulse, rhythm, pitch, timbre, structure, and dynamics. There was a lot of content, and it would be worthwhile in returning to these elements specifically in future sessions across the rest of the year, particularly in terms of pulse and rhythm, given their close synergies with the building blocks of language. The programme and evaluation are ongoing, although these have been partially suspended because of the Covid-19 epidemic in which nurseries and schools in the UK are currently closed.

In terms of the mentoring and its quality, the literature on mentoring suggests that its effectiveness results from 'generally good faith efforts by all parties' that foster new personal and professional relationships (Langdon et al., 2016, p159), and with positive 
mentoring outcomes for both mentors and mentees (Ehrich et al., 2004). Positive outcomes should include demonstrable collegiality (collaboration, networking, sharing ideas and knowledge), reflection, professional development and personal satisfaction (reward, growth) (Powell, 2018). Although the detailed evidence for each of these attributes was not necessarily explicit over these three sessions, given that the programme had only three two-hour sessions and continues in 2020 (although not at present when nurseries and schools are essentially close because of Covid-19), nevertheless, the groundwork was laid and the relationships established between mentor and mentees (and with each other) were positive.

Given the group-based, essentially off-site, nature of the programme (apart for staff of the school hosting the session) this form of mentoring makes particular demands on the mentor unless they are able to visit each participant and observe and share their music making at first hand. In particular, the literature (such as by Conway \& Hodgman, 2006) suggests that effective mentor qualities in music include: (i) strong knowledge of subject matter-which was clearly evidenced in this programme; (ii) a compatible philosophy of music education-the mentors demonstrated an excellent craft knowledge of musical behaviours, development and repertoire in early years settings which will have resonated with the adult participants; (iii) excellent music and teaching skills-again evidenced here; as well as (iv) being a good listener, organised, personable, and professional-again these qualities were observed. The capacity to nurture and affirm (Smith, 2005) has also been identified as a key element of effective mentoring in music, and this was also evidenced, notwithstanding the group-based design of the experience.

One way in which the programme could be strengthened - in addition to a spiral design in which key elements recur across the year - would be to encourage individual participants to bring audio and/or video examples of sound/music making to sessions in order to share with the mentors and others in the group. This would provide a solid evidence base that they were really getting on the inside of the 'Sound Communities' programme philosophy and content. 


\section{Summary and conclusions}

Overall, the evidence from these recent initiatives in the UK and Australia suggests that it is possible for effective mentoring to address the challenge of ensuring that early years nonmusic specialists are enabled to deepen and develop their knowledge, understanding and skills in music education. Such partnerships between specialists (who have a particular expertise in music) and generalists (who have a deep knowledge of their young children) can enrich everyone involved. It can also ensure that such professional development echoes key features of 'close-to-practice' research (Wyse, Brown, Oliver \& Poblete, 2018) that is characterised by being grounded in real-world challenges faced by practitioners.

Furthermore, in the example research findings from the cases provided above, there were positive impacts on young children as a direct result of the expert mentoring received by their generalist early years practitioners. The benefits that were evidenced were:

(i) musical-embracing increased singing competency in two separate studies, one in Australia and one in England (Barrett et al, 2020; Welch et al, 2020); and also in general musical behaviours and development (Ockelford, in Knight, 2018), as measured by the Sounds of Intent in the Early Years framework (Voyajolu \& Ockelford, 2016); and

(ii) other-than-musical - positive changes being reported in children's attitudes to and engagement with music (Barrett et al, 2020); in improved reading competency and also aspects of executive function - being related to response inhibition, phonological working memory and executive-loaded working memory (Welch et al, 2020); and also social and emotional development (Knight, 2018).

In summary, the research evidence suggests that young children are inherently musical, but that they have unequal access to opportunities to realise their musical potential. One of the common limitations derives from the limited pedagogical experience in music that is found in the early years' workforce - the people who work in pre-school and the beginning years of Primary school, whether as Principals, teachers or teaching assistants. This system-wide pedagogical shortcoming can be addressed, however, through the provision of effective, class-based mentoring by specialist early years music educators. There is also a clear role 
for researchers to undertake close-to-practice research in partnership with early years colleagues that can be translated into principles of effective music pedagogy with young children (such as found in the 'Inspire Music' project outcomes in England, see https://www.inspire-music.org).

\section{References}

Alemán , X., Duryea, S., Guerra, N.G., McEwan, P.J., Munoz, R., Stampini, M., \& Williamson, A.A. (2017). The Effects of Musical Training on Child Development: A Randomized Trial of El Sistema in Venezuela. Prevention Science, 18(7), 865-878. DOI 10.1007/s11121-016-0727-3.

Anvari, S.H., Trainor, B.J., Woodside, J., \& Levy, B.A. (2002). Relations among musical skills, phonological processing and early reading abilities in pre-school children. Journal of Experimental Child Psychology, 83, 111-130.

Auh, M. S. (2004). Changes in perceptions of confidence in teaching music by preservice students. Bulletin of the Council for Research in Music Education, 11-18.

Ballantyne, J. (2006). Reconceptualising preservice teacher education courses for music teachers: the importance of pedagogical content knowledge and skills and professional knowledge and skills. Research Studies in Music Education, 26, 37-50. doi: 10.1177/1321103X060260010101

Barrett, M.S., Flynn, L. M., Brown, J.E., \& Welch, G.F. (2019). Beliefs and Values About Music in Early Childhood Education and Care: Perspectives from Practitioners. Frontiers in Psychology. 10/724. doi: 10.3389/fpsyg.2019.00724

Barrett, M., Zhukov, K., \& Brown, J.E., \& Welch, G.F. (2020). Evaluating the impact of a generalist teacher-led music program on early childhood school children's singing skills and attitudes to music. Psychology of Music, 48(1), 120-136.

Barrett, M.S., Zhukov, K., Welch, G.F. (2019): Strengthening music provision in early childhood education: a collaborative self-development approach to music mentoring for generalist teachers. Music Education Research. https://doi.org/10.1080/14613808.2019.1647154

Bath, N., Daubney, A., Mackrill, D., \& Spruce, G. (2020). The declining place of music education in schools in England. Children \& Society. 1-15. DOI: 10.1111/chso.12386

Berg, M. H., \& C. Conway. (2016). The Design and Implementation of the ASTA Mentor Program: Perceptions of Program Developers and Mentor Preparation Workshop Participants. String Research Journal 7: 63-81.

Bhachu, D.K. (2019). Facilitating musical learning in Scottish Primary Schools: An interviewbased study of generalist primary teachers', primary music specialists' and community music practitioners' views and experiences. Unpublished PhD Thesis. University of Edinburgh.

Biasutti, M., \& Seddon. F. (2008). Non-music specialist trainee Primary school teachers' confidence in teaching music in the classroom. Music Education Research 10(3), 403421. 
Biasutti, M., Welch, G. F., MacRitchie, J., McPherson, G. E., Himonides, E. (Eds.) (2020). The Impact of Music on Human Development and Well-Being. Lausanne: Frontiers Media SA. doi: 10.3389/978-2-88963-683-9

Blacking, J. (1976). How musical is man? London: Faber \& Faber.

Bowmer, A.R, Mason, K.C., Knight, J., \& Welch, G.F. (2018). Investigating the impact of a musical intervention on preschool children's executive function. Frontiers in Psychology (Developmental Psychology). 9/2389 doi: 10.3389/fpsyg.2018.02389.

CASE (1967). Children and their primary schools: A report of the Central Advisory Council for Education (England). Vol. 1. London: HMSO. Retrieved from http://www.educationengland.org.uk/documents/plowden/plowden1967-1.html

Chua, S. L., \& Welch, G.F. (2019). A quantitative study of experiences impacting music teacher development. Psychology of Music. DOI: 10.1177/0305735619873387.

Clift, S., Mackenzie, K., and Bushell, F. (2007). The MusicStart Project. An exaluation of an Isle of Wight Early Years Music Initiative. Canterbury: Canterbury Christ Church University.

Conway, C. M., \& Hodgman, T. M. (2006). Mentoring. In C. M. Conway \& T. M. Hodgman (Eds.). Handbook for the Beginning Music Teacher, (pp.201-209). Chicago, IL: GIA Publications.

DES (1992). Curriculum Organisation and Classroom Practice in Primary Schools. London: Department of Education and Science.

de Vries, P. (2013). Generalist teachers' self-efficacy in primary school music teaching. Music Education Research, 15(4). 375-391.

DFE (2010). Statement of Intent 2010 - Addendum (The English Baccalaureate). London: Department for Education. [December 2010, Addendum to the White Paper, The Importance of Teaching, published 24 October 2010].

DFE (2011). The Importance of Music. A National Plan for Music Education. London: Department for Education \& Department for Culture, Media and Sport.

DFE (2017). Statutory framework for the early years foundation stage: Setting the standards for learning, development and care for children from birth to five. London: Department for Education.

DFE (2019). English Baccalaureate (EBacc). London: Department for Education.

Digby, J. (2020). Teacher confidence to facilitate children's musical learning and development in the Reception Year at school. Unpublished PhD Thesis, University College London.

Eraut, M. (2011). Informal Learning in the Workplace: Evidence on the Real Value of Workbased Learning (WBL). Development and Learning in Organizations, 25(5): 8-12.

Ehrich, L. C., Hansford, B., \& Tennent, L. (2004). Formal Mentoring Programs in Education and Other Professions: A Review of Literature. Educational Administration Quarterly 40(4): 518-540.

Fasano, M.C., Semeraro, C., Cassibba, R., Kringelbach, M.L., Monacis, L., de Palo, V., Vuust, P., \& Brattico. (2019). Short-Term Orchestral Music Training Modulates Hyperactivity and Inhibitory Control in School-Age Children: A Longitudinal Behavioural Study. Frontiers in Psychology, 10:750.

https://doi.org/10.338g/fpsyg.2019.00750

Forgeard, M., Winner, E., Norton, A. \& Schlaug, G. (2008). Practicing a musical instrument in childhood is associated with enhanced verbal ability and nonverbal reasoning. PLoS One, 3(10), e3566. doi:10.1371/journal.pone.0003566.

Figueiredo, S., Soares, J. \& Schambeck, R.F. (2014). Current perspectives and challenges for the preparation of music teachers in Brazil. In S. Figueiredo, J. Soares, \& R.F. 
Schambeck (Eds.) The Preparation of Music Teachers: A Global Perspective. (pp4566). Porto Alegre, Brazil: ANPPOM.

HMSO (1988). Education Reform Act 1988. London: HMSO.

Haimson, J., Swain, D., \& Winner, E. (2011). Are mathematicians more musical than the rest of us? Music Perception, 29, 203-213.

Hallam, S., Burnard, P., Robertson, A., Saleh, C., Davies, V., Rogers, L., \& Kokatsaki. (2009). Trainee primary-school teachers' perceptions of their effectiveness in teaching music. Music Education Research, 11(2), 221-240. doi: 10.1080/14613800902924508.

Hennessy, S. (2000). Overcoming the red Feeling: The development of confidence to teach music in Primary school amongst student teachers. British Journal of Music Education 17(2): 183-196.

Hennessy, S. (2010). La formazione musicale degli insegnanti della scuola primaria [The music education of primary school teachers]. In Biasutti, M. (Ed.), Educare a educare. Ricerche sulla formazione degli insegnanti di musica [Educating to educating: research in educating music teachers] (pp. 23-66). Lecce (Italy): Pensa Multimedia.

Hennessy, S. (2017). Approaches to increasing the competence and confidence of student teachers to teach music in primary schools. Education 3-13, 45(6), 689-700.

Hodges, D. (2019). Music through the lens of cultural neuroscience. In M. Thaut \& D. Hodges, (Eds.) The Oxford Handbook of Music and the Brain (pp.18-40). New York: Oxford University Press.

Holden, H., \& Button, S. (2006). The teaching of music in the primary school by the nonspecialist. British Journal of Music Education, 23(1), 23-38.

Jeanneret, N. (1997). Model for developing preservice primary teachers' confidence to teach music. Bulletin of the Council for Research in Music Education, 133, 37-44.

Knight, J., Stansall, V., Bowmer, A., Mason, K., Voyajolu, A., Ockelford, A., \& Welch, G. (2018). 'Music for Change' 2015-2018: Enhancing the school readiness of children in challenging circumstances. London: Creative Futures. https://e2c1aooc-fac6-4afbace74b7f 5 f2393fo.filesusr.com/ugd/b407eo_cg8796gob9444f81ba6641ce10fd 515f.pdf

Kram, K. E. (1985). Mentoring at Work: Developmental Relationships at Work. Glenview, IL: Scoot, Foresman and Company.

Kulset, N.B., \& Halle, K. (2019). 'Fake it till you make it'. How do kindergarten staff in kindergartens with a music profile talk about their musical identity? Proceedings of the gth Conference of the European Network of Music Educators and Researchers of Young Children (MERYC), 2019.

Langdon, F. J., Alexander, P. A., Farquhar, S., Tesar, M., Courtney, M. G. R., \& Palmer. M. (2016). Induction and Mentoring in Early Childhood Educational Organizations: Embracing the Complexity of Teacher Learning in Contexts. Teaching and Teacher Education 57: 150-160.

Letts, R. (2015). Tertiary pre-service courses for primary school specialist music teachers. Music Trust of Australia. http://musicinaustralia.org.au/index.php?title=Tertiary_Preservice_Courses_for_Primary_School_Specialist_Music_Teachers

Linnavelli, T., Putkinen, V., Lipsanen, J., Huotilainen, M., \& Tervaniemi, M. (2018). Music playschool enhances children's linguistic skills. Nature Scientific Reports, 8: 8767, DOI:10.1038/s41598-018-27126-5 
Loui, P., Raine, L.B., Chaddock-Heyman, L., Kramer, A.F. \& Hillman, C.H. (2019). Musical Instrument Practice Predicts White Matter Microstructure and Cognitive Abilities in Childhood. Frontiers in Psychology, 10:1198. doi: 10.3389/fpsyg.2019.01198.

McCullough, L. (2006). "I don't Know Anything About Music": An Exploration of Primary Teachers' Knowledge About Music in Education. Unpublished PhD Thesis, Northumbria University, UK.

Mills, J. (1989). The generalist primary teacher of music: a problem of confidence. British Journal of Music Education, 6, 125-138. doi: 10.1017/S0265051700007002.

Mota, G. (2015). Twenty five years of music teachers' education in Portugal: Revisiting history. In S. Figueiredo, J. Soares, \& R.F. Schambeck (Eds.) The Preparation of Music Teachers: A Global Perspective. (pp241-264). Porto Alegre, Brazil: ANPPOM.

Moreno, S., Friesen, D., \& Bialystok, E. (2011). Effect of music training on promoting preliteracy skills: Preliminary causal evidence. Music Perception, 29, 165-172.

Patel, A.D. (2008). Music, language and the brain. Oxford University Press, New York.

Peeters, J., Rohrmann, T., \& Emilsen, K. (2015). Gender balance in ECEC: why is there so little progress? European Early Childhood Education Research Journal, 23, 302-314. doi: 10.1080/1350293X.2015.1043805

Pitt, J. \& Arculus, C. (2018). SALTMusic Research Project: Youth Music Report. Great Yarmouth: Great Yarmouth Community Trust.

Politimou, N., Dalla Bella, S., Farrugia, N. \& Franco, F. (2019). Born to Speak and Sing: Musical Predictors of Language Development in Pre-schoolers. Frontiers in Psychology, 10:948. doi: 10.3389/fpsyg.2019.00948.

Poulter, V., \& Cook, T. (2020). Teaching music in the early years in schools in challenging circumstances: developing student teacher competence and confidence through cycles of enactment. Educational Action Research. https://doi.org/10.1080/09650792.2020.1765185

Powell, S. R. (2018). Structure and Agency in Novice Music Teaching. Research Studies in Music Education 41: 206-218. doi:10.1177/1321103X18794514.

Putkinen, V., Huotilainen, M., \& Tervaniemi, M. (2019). Neural Encoding of Pitch Direction Is Enhanced in Musically Trained Children and Is Related to Reading Skills. Frontiers in Psychology 10:1475. doi: 10.338g/fpsyg.2019.01475

Rauscher, F.H., \& Hinton, S.C. (2011). Music instruction and its diverse extra-musical benefits. Music Perception, 29, 215-226

Ruddock, E., \& Leong, S. (2005). 'I am unmusical!': the verdict of self-judgement. International Journal of Music Education, 23(1), 9-22.

Russell-Bowie, D. (2009). What me? Teach music to my primary class? Challenges to teaching music in primary schools in five countries. Music Education Research, 11, 23-36. doi: 10.1080/14613800802699549.

Schellenberg, E.G. (2004). Music lessons enhance IQ. Psychological Science, 15, 511-514.

Schellenberg, E.G. (2016). Music training and nonmusical abilities. In S. Hallam., I. Cross., \& M. Thaut (Eds.). The Oxford Handbook of Music Psychology ( $2^{\text {nd }}$ Edition). DOI: 10.1093/oxfordhb/9780198722946.013.28.

Schlaug, G. (2015). Musicians and music making as a model for the study of brain plasticity. Progress in Brain Research, 217, 37-55. http://dx.doi.org/10.1016/bs.pbr.2014.11.020

Seddon, F., \& Biasutti, M. (2008). Non-music specialist trainee primary school teachers' confidence in teaching music in the classroom. Music Education Research, 10, 403421. doi: $10.1080 / 14613800802280159$. 
Smith, M. V. (2005). Modern Mentoring: Ancient Lessons for Today. Music Educators Journal 92(2): 62-67.

Stakelum, M. (2008). Creating a musical world in the classroom: application of a Bourdieuan approach towards understanding teacher practice. British Journal of Music Education, 25, 91-102. doi: 10.1017/S0265051707007747.

Steinbrink, C., Knigge, J., Mannhaupt, G., Sallat, S., \& Werkle, A. (2019). Are Temporal and Tonal Musical Skills Related to Phonological Awareness and Literacy Skills? Evidence From Two Cross-Sectional Studies With Children From Different Age Groups. Frontiers in Psychology. 10:805. doi: 10.3389/fpsyg.2019.00805

Stunell, G. (2010). Not musical? Identity perceptions of generalist primary school teachers in relation to classroom music teaching in England. Action Criticism, and Theory for Music Education 9, 79-107. http://act.maydaygroup.org/articles/Stunellg_2.pdf

Voyajolu, A., \& Ockelford, A. (2016). Sounds of Intent in the Early Years: A proposed framework of young children's musical development. Research Studies in Music Education, 38(1), 93-113.

Welch, G.F. (1998). Early Childhood Musical Development. Research Studies in Music Education, 11, 27-41.

Welch, G.F. (2011). The arts and humanities and the 'English Baccalaureate': STEAM not STEM. Research in Secondary Teacher Education, 1(2), 29-31.

Welch, G.F. (2012a). The arts and humanities, technology and the 'English Baccalaureate': STEAM not STEM. Journal of Music, Technology and Education, 4(2/3), 245-250. [doi: 10.1386/jmte.4.2-3.245_1]

Welch, G.F. (2012b). Musical creativity, biography, genre and learning. In D.J. Hargreaves., D.E. Miell., \& R.A.R. MacDonald (Eds.), Musical Imaginations. Multidisciplinary perspectives on creativity, performance and perception. (pp. 385-398). Oxford: Oxford University Press.

Welch, G.F., \& Bowmer, A. (2018). 'Music for Change' An action-research, two-year, multidisciplinary collaboration between musicians and Speech and Language Therapists. London: Creative Futures.

Welch, G. F., \& Henley, J. (2014). Addressing the challenges of teaching music by generalist1 Primary school teachers. Revista da ABEM, 22(32).

http://www.abemeducacaomusical.com.br/revistas/revistaabem/index.php/revistaa bem/article/view/459

Welch, G.F., Himonides, E., Saunders, J., Papageorgi, I., \& Sarazin, M. (2014). Singing and social inclusion. Frontiers in Psychology, 5:803. doi: 10.3389/fpsyg.2014.00803.

Welch, G.F., \& McPherson, G. (2018). Commentary: Music education and the role of music in people's lives. In G. McPherson, \& G.F. Welch, (Eds.), Music and Music Education in People's Lives: An Oxford Handbook of Music Education. (pp3-18). New York: Oxford University Press.

Welch, G.F., \& Preti, C. (2019). Singing as inter- and intra-personal communication. In: G. Welch, D.M. Howard, \& J. Nix (Eds). The Oxford Handbook of Singing. 10.1093/oxfordhb/9780199660773.013.73

Welch, G.F., Purves, R., Saunders, J., Mason, K., \& Bowmer, A. (2020). 'Sing Every Day': An evaluation of a VOCES8 Foundation school-based singing project in Hackney, London 2019. London: VOCES8 Foundation.

Williams, K.E., Barrett, M.S., Welch, G.F., Abad, V., \& Broughton, M. (2015). Associations between early shared music activities in the home and later child outcomes: 
Findings from the Longitudinal Study of Australian Children. Early Childhood Research Quarterly, 31, 113-124. http://dx.doi.org/10.1016/j.ecresq.2015.01.004 Wyse, D., Brown, C., Oliver, S. \& Poblete, X. (2018). The BERA Close-to-Practice Research Project: Research Report. London: British Educational Research Association. https://www.bera.ac.uk/researchers-resources/publications/bera-statement-onclose-to-practice-research

Zeserson, K., Welch, G., Burn, S., Saunders, J., \& Himonides, E. (2014). Inspiring Music for All: next steps in innovation, improvement and integration. London, UK: Paul Hamlyn Foundation review of music in schools.

Zuk, J., Perdue, M.V., Becker, B., Yu, X., Chang, M., Raschle, N.M., \& Gabb, N. (2018). Neural correlates of phonological processing: Disrupted in children with dyslexia and enhanced in musically trained children. Developmental Cognitive Neuroscience, 34, 82-91. doi: 10.1016/j.den.2018.07.001 